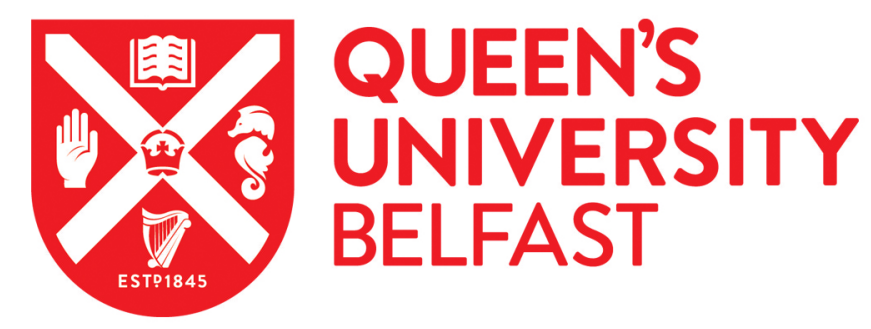

\title{
The impact of the summer 2007 forest fires in Greece: Recent environmental mobilizations, cyber-activism and electoral performance
}

Karamichas, J. (2007). The impact of the summer 2007 forest fires in Greece: Recent environmental mobilizations, cyber-activism and electoral performance. SOUTH EUROPEAN SOCIETY AND POLITICS, 12(4), 521-533. https://doi.org/10.1080/13608740701731473,

https://doi.org/ttps://doi.org/10.1080/13608740701731473

Published in:

SOUTH EUROPEAN SOCIETY AND POLITICS

Queen's University Belfast - Research Portal:

Link to publication record in Queen's University Belfast Research Portal

\section{General rights}

Copyright for the publications made accessible via the Queen's University Belfast Research Portal is retained by the author(s) and / or other copyright owners and it is a condition of accessing these publications that users recognise and abide by the legal requirements associated with these rights.

Take down policy

The Research Portal is Queen's institutional repository that provides access to Queen's research output. Every effort has been made to ensure that content in the Research Portal does not infringe any person's rights, or applicable UK laws. If you discover content in the Research Portal that you believe breaches copyright or violates any law, please contact openaccess@qub.ac.uk. 
This article was downloaded by: [Queens University]

On: 17 November 2010

Access details: Access Details: [subscription number 769793645]

Publisher Routledge

Informa Ltd Registered in England and Wales Registered Number: 1072954 Registered office: Mortimer House, 3741 Mortimer Street, London W1T 3JH, UK

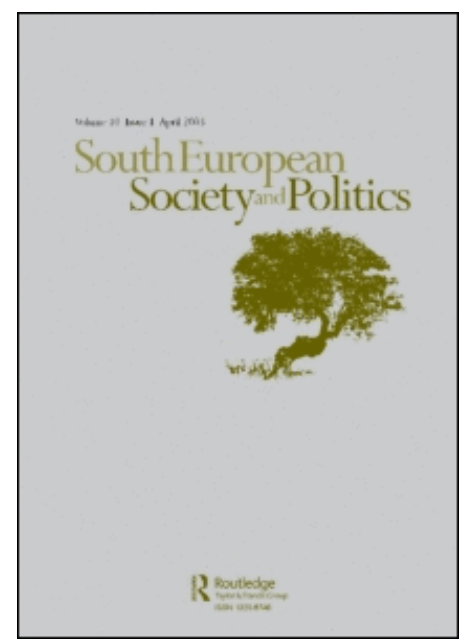

\section{South European Society and Politics}

Publication details, including instructions for authors and subscription information:

http://www.informaworld.com/smpp/title $\sim$ content=t713636479

The Impact of the Summer 2007 Forest Fires in Greece: Recent Environmental Mobilizations, Cyber-Activism and Electoral Performance

John Karamichas

To cite this Article Karamichas, John(2007) 'The Impact of the Summer 2007 Forest Fires in Greece: Recent Environmental Mobilizations, Cyber-Activism and Electoral Performance', South European Society and Politics, 12: 4, 521 - 533

To link to this Article: DOI: 10.1080/13608740701731473

URL: http://dx.doi.org/10.1080/13608740701731473

\section{PLEASE SCROLL DOWN FOR ARTICLE}

Full terms and conditions of use: http://www.informaworld.com/terms-and-conditions-of-access.pdf

This article may be used for research, teaching and private study purposes. Any substantial or systematic reproduction, re-distribution, re-selling, loan or sub-licensing, systematic supply or distribution in any form to anyone is expressly forbidden.

The publisher does not give any warranty express or implied or make any representation that the contents will be complete or accurate or up to date. The accuracy of any instructions, formulae and drug doses should be independently verified with primary sources. The publisher shall not be liable for any loss, actions, claims, proceedings, demand or costs or damages whatsoever or howsoever caused arising directly or indirectly in connection with or arising out of the use of this material. 


\title{
SOUTH EUROPEAN ATLAS
}

\section{The Impact of the Summer 2007 Forest Fires in Greece: Recent Environmental Mobilizations, Cyber-Activism and Electoral Performance}

\author{
John Karamichas
}

\begin{abstract}
This report circumambulates around the environmental issue, examining mobilizations in favour of public access to the seafront and protest events against the recent devastating forest fires. By framing this discussion within existing scholarly contributions on related dimensions of the environmental issue (environmental consciousness, grassroots environmental contestation) in Southern Europe in general and Greece in particular, it suggests that the environmental mobilization dynamic in Greece has been infused with a new, global, mobilizing resource that offers new avenues to evaluate the potency of Greek civil society. Finally, the article discusses the results of the 2007 national elections and ponders the chances of political ecology becoming a permanent feature of Greek parliamentary politics.
\end{abstract}

Keywords: Citizen Initiatives; Civil Society; Blogs; Forest Fires; General Elections; Greece

The current period appears, in many respects, to represent a landmark for social and political developments in Greece. A number of interlinked developments substantiate this claim. On the one hand, we see a proliferation of citizen initiatives over quality of life issues which have targeted the core of some of the structural deficiencies characterizing the Greek context whilst taking advantage of the opportunities offered for message dissemination and action coordination by new technologies. On the other, the general elections of 16 September 2007 altered the usual make-up of the Greek parliament. 


\section{J. Karamichas}

The centrepiece, around which the discussion of these issues will be organized, is the environmental problem. This is not arbitrary, but a choice that reflects on some recent groundbreaking events. It is also consistent with some of the recent challenges to well-entrenched conceptions about certain social dynamics in the Greek social context and finds resonance with some key points made in contemporary social theorizations. Particularly relevant are the theoretical perspectives offered by the 'reflexive modernization' thesis of Ulrich Beck and Anthony Giddens, which elevate the environmental issue to the core area of social conflict in late modernity.

Consequently, this review starts with a brief evaluation of environmental concerns in Greece. It suggests that the type of environmental concern exhibited by the Greeks happens to correspond with particular forms of societal activism, which can also be appreciated through the employment of a much wider socio-historical prism. This can also account for certain structural limitations that inhibit the appropriate functioning of democratic institutions in the country. It continues with a discussion of a number of recent local and national mobilizations over environmental issues (broadly defined) and culminates with an appraisal of the results of the 2007 national elections, with reference to the impact of the devastating forest fires that preceded them.

\section{Greek Society and the Environment}

When engaging with the environmental dimension in the Southern European context, it is inevitable to make, at least, a passing remark upon the 'Mediterranean Syndrome' (La Spina \& Sciortino 1993) and 'Southern Problem' (Pridham \& Cini 1994). These formulations have very much dominated the discussion on the ability of the southern European Union (EU) member states to comply with EU environmental directives. Both formulations single out the lack of a civic culture that can translate into an interest in engagement with collective goods that do not directly impact on what is seen as the familial and local, and the permeation of patronage and clientelist practices into the public administration which often result in the latter's inept functioning. One of the variables usually used to substantiate these points is the relatively low membership in environmental associations in Southern Europe when compared with the EU average. For instance, the spring 1995 Eurobarometer (p. 41) highlights that only six per cent of Greeks were members of environmental organizations. In the same period, the membership of ecological and pacifist groups in Spain was estimated at four per cent (Mota 1999, pp. 44, 54). However, it is worth noting that, if compared with the extremely low membership scores in both countries during the 1980s, these percentages represent a substantial increase. In fact, this is one of the changes that took place in Greece during the 1990s, leading Close $(1998 ; 1999)$ to conclude that the environmental problematic has operated to strengthen civil society in Greece.

At the end of the 1990s, the Greek public professed the highest concern for environmental protection and the fight against pollution in the EU, with 91 per cent supporting the view that this is an urgent and immediate problem (European Commission 1999, p. 91). This professed concern has been qualified by some social 
scientists as mainly focused around instances of local environmental deterioration rather than on national or global environment problems (global warming, depletion of the ozone layer, etc.). The latter can potentially give rise to increased membership of environmental organizations and/or lead directly to an alteration of behavioural disposition toward environmentally sound behaviour (Hofrichter \& Reif 1990). However, even in cases where the Greek public, along with its Southern European counterparts, professed high levels of concern over global environmental issues, they seemed to lack a clear knowledge of their causes and potential effects (Rüdig 1995). Thus, it could be argued that the low propensity of Greeks to become members of environmental organizations (despite the noticeable increase in those doing so) appears to match the 'personal complaint' character of the environmental concern that predominates among the Greek public.

In addition, contrary to the modernizing rhetoric that has been promoted, and some notable changes introduced by the two most recent Greek governments in an attempt to challenge the structural deficiencies of the Greek socio-political pattern and support the rationalization of state administration, the decision-making process is still stained by a lack of public engagement and a top-down approach that reproduces these deficiencies and more often than not results in confrontation. The environmental dimension adds to this confrontation further considerations. Indeed, one may ponder: are the grassroots mobilizations that engulf this confrontation a result of what Rohrschneider (1988) calls 'selfishness' or 'virtue'? There is no immediate answer to this question.

Grassroots mobilizations against a developmental project in a Greek locality which is deemed to be detrimental to the local environment and health of the inhabitants acquire a different meaning when no similar opposition has developed in the case of other projects with similar deleterious effects on the local environment but with substantial financial gains for some of the locals. This was certainly the case of local environmental mobilizations during the 1970s and 1980s. Indeed, the environmental concern leading to those mobilizations was undoubted confined to the 'personal complaint' category albeit there were also some economic motivations underpinning them, such as the fact that some of the projects opposed by the locals were perceived to be a serious obstacle for the further tourist development of the area. In terms of a more concerted type of environmentalism, the most noticeable expression of political ecology in Greece was

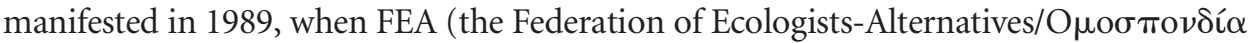

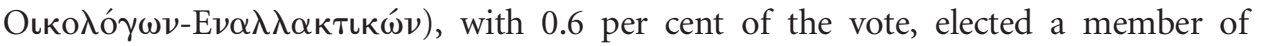
parliament (MP). This was made possible by an unusually open electoral law (passed shortly before the election) and a propensity for protest voting (ie voting to demonstrate unhappiness with the political system) that was encouraged by the serious accusations of economic scandals confronting the Greek government at the time. By 1992, FEA had dissolved as a result of an intensive factionalist conflict that permeated its ranks at an early stage of its organizational development (see Karamichas \& Botetzagias, 2003).

A recent study has shown that the Greeks, along with their South European counterparts and irrespective of their low membership in environmental organizations, exhibited the highest propensity to engage in environmental protest in Western 


\section{J. Karamichas}

Europe from the late 1980s to the late 1990s (Kousis et al. 2001). Concluding her study of grassroots mobilizations in Greek localities during the 1970s and 1980s, Kousis (1994) states that 'civil society in post-war Greece has been pressuring the state to fulfil its legitimation function'. Nowadays, one would be hard pushed to argue that Kousis' statement has lost its relevance. Recent instances of local environmental mobilizations still tend to challenge the inadequate or even complete lack of implementation of existing legal frameworks and even respect for constitutional rights, instead of advocating a complete reformulation or even break-up of the existing institutional framework (of parliamentary democracy), as some of the most radical sectors of the environmental movement tend to do.

One may bring to mind the local mobilizations against the construction of a High Voltage Power Station in the two Athens municipalities of Argyroupolis and Ilioupolis, as that project was perceived to be detrimental to the health of the local residents, the environment and the local area in general. The campaign by the locals lasted for a year (March 2002 to March 2003) and ranged from lawsuits, petitions to the Council of

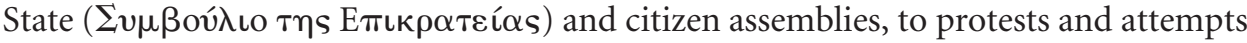
to physically obstruct the project. The government initially employed a discourse emphasizing the need for national unity and restraint, as the country was in the final stages of preparations to host the 2004 Olympic Games and the construction of the power station had been incorporated into the special law of 2001 for 'Core Olympic Projects'. Subsequently, violent repression was used to quell the mobilizations. Most importantly, the Greek authorities failed to engage the public in any form of consultation prior to the start of work on the project, for example, through the use of something similar to the 'public inquiry' procedure used in the UK (Karamichas 2005). We can also add the more or less systematically recurring local mobilizations against the location of waste disposal facilities which often interrupt waste collection and add to the unpleasant odour of Athenian exhaust fumes. The location of waste disposal facilities in some of the most deprived and disadvantaged areas of the country may even tempt some to see these mobilizations in the context of campaigns that first appeared in the United States and offered the foothold for the development of what is known as the environmental justice movement. This would be perfectly legitimate, since in the Greek case too we are confronted with a similar manifestation of unequal risk distribution in a democratic polity.

Some works have argued that the well-documented weakness of Greek civil society should be challenged or, at least, complemented. More recently, a popular edited collection on Greek civil society has put forward the view that civil society in Greece cannot, and should not, be measured by traditional quantitative indicators, such as membership in civic associations. It is argued that such indicators are incapable of capturing the informal essence of civil society, which is manifested in spontaneous acts of solidarity in times of unforeseen natural disasters, such as earthquakes (Sotiropoulos 2004). This publication in many respects complements an earlier work that operates along the same lines of reasoning whilst referring, among other things, to the voluntarism exhibited by members of the Greek public in the protection of forests 
from fires (Sotiropoulos 1996). As mentioned earlier, some have gone even further, claiming that the environmental problematic has operated to strengthen Greek civil society (Close 1998; 1999). All these hypotheses can be, rather uncomfortably, put to the test following the recent forest fires that destroyed a substantial part of the natural wealth of the Greek countryside. The extent of the destruction may potentially make some of the claims in the Greek report to the 2002 Earth Summit in Johannesburg, concerning the variety and wealth of rare flora and fauna that the country possesses, appear to be a recollection from the distant past. The ramifications of the devastation caused by the forest fires can potentially be evaluated in relation to a number of sociopolitical dimensions, including changes in the character of societal activism and the results of the most recent national elections.

One would be justified in wondering at this stage about the extent to which the forest fires of 2007 constitute such an important turning point. After all, summer forest fires have been recurring every year for decades, with an average land impact of 74,100 acres per year since the 1960s. This increased substantially to an average of 247,000 acres during the 1990s (Eleftherotypia, 2 February 2001), which actually represents the lowest score in Southern Europe (Institute for Environment and Sustainability [IES] 2005) during this period. Notwithstanding the innocent causes (summer droughts, accidents, etc.) behind many of those fires, one would be hard pushed to deny the fact that anarchic planning development in conjunction with inefficient fire protection measures has aggravated the forest fires problem.

Moreover, it is worth noting that, prior to 2007, the worst forest fires record in terms of both magnitude and damage occurred in 2000. The toll of 423,000 acres of burned land $^{1}$ coincided with a planned amendment of Article 24 of the Constitution (the Forest Protection Article) by the then government of the Socialist Party (PASOK). The forest fires of 2007 also coincided with a planned amendment to Article 24, this time under the government of the right-wing New Democracy (ND). The record of 2007, in terms of both acreage $(667,000$ acres according to EFFIS [European Forest Fires Information System] data published in Eleftherotypia, 16 September 2007) and death toll (74 deaths) make the 2000 forest fires pale into insignificance. Both attempts to amend the most important institutional guarantee of environmental protection in Greece were seen as a disguised attempt to facilitate the plans of some insidious developers who had been targeting the real estate potential of areas in or close to the countryside for a long time. ${ }^{2}$ Both attempts were opposed by the parliamentary left parties and the environmental movement.

The question arises whether the forest fires of 2007 constitute a turning point, signifying the beginning of a new societal approach to the environmental issue. In this respect, a key issue concerns the extent of the role of public vigilance in guaranteeing the rejuvenation of the affected forest areas. There are many more possibilities for this than in the past, thanks to the use of new technology to mobilize the public, the continuous popularization of debates about environmental degradation across Europe, and the work expected in this direction by the parliamentary parties of the left, which were strengthened in the 2007 election. 


\section{J. Karamichas}

The 2007 Seaside Protests (May-August 2007)

One of the most recent manifestations of the recurring theme of mobilizations that essentially pressure the state to 'fulfil its legitimation function' was the direct action to reclaim the seaside in two coastal municipalities (Helliniko, Moschato) after May 2007. The local authorities, with the active support of local citizens, dismantled the wire fences and other structural obstacles-erected by some of the many nightclubs operating in the coastal zone of Athens-that were blocking free access to the local beaches. With their use of non-violent direct action, the mobilizers were defending the constitutionally inscribed protection of the seashore and a more specific ruling by the Council of State which prohibits any forms of use that block free and unobstructed access to the beaches. This is not the first time that citizens have mobilized over this issue. In fact, the presidential decree of March 2004 outlining the rules governing the protection of the coastal zone was issued as a result of a wave of similar mobilizations.

However, in the most recent round, the mobilizers, armed with the conviction that the state authorities had failed to meet their legal obligations to quell the illegal occupation of the seashore by private interests, were more persistent and determined to meet their aim. Characteristically, the elected mayor of one of the two municipalities even went on hunger strike, in protest both against the repeated attempts made by the private interests that have been preying on the coast for decades to block free access and against the partiality shown by the police authorities against the mobilized public. This act of self-immolation received widespread media interest and further coverage for the mobilizations. The latter only ended in mid-August 2007 after a successful push by the locals to guarantee permanent free access to the seashore under the watchful eyes of legal representatives, some prominent and popular political figures of the left, the mass media and the police forces-the latter now with instructions to take appropriate action against any possible repressive interventions by nightclub bouncers to intimidate the local mobilizers.

The extent to which the success of these mobilizations signifies a permanent end to the obstruction of free access to the Athenian seashore is debatable, since this development would require institutional actors to choose to ignore various private interests and abide by the existing legal framework. It is quite certain though that any violation of this kind would meet significant resistance from the locals and their allies. In attempting a more substantive evaluation of the potential permanency of the impact of environmental mobilizations, it is important not to lose sight of the fact that any permanency is, naturally, also conditioned. The forest fires that devastated a large part of Greece during the summer months of 2007 had an impact that on many counts was much more substantial than one is likely to expect from an event like a forest fire-an event that has sometimes been used as a simile for social events of high temporal intensity which then fall short of expectations in terms of permanency after they are 'extinguished'. 


\section{Cyber-activism and Forest Fires}

The forest fires brought to public attention a new way of provoking, promoting and organizing protest activities. The use of new technological media like short message service (SMS), digital cameras and the advanced functions (photographs, videos) provided by the latest generation of mobile phones, in conjunction with the ease of transmitting images to a global audience by simply uploading them to a wide range of webpages, has brought to the fore a liberalization of information dissemination. It would not be an exaggeration to suggest that this represents an undisputable example of what Friedman (2006) calls the 'flatness' of the world brought about by the dynamic of globalization. There is an ever growing literature on the use of the internet by social movement actors, so any substantive reference to it would go substantially beyond the sphere of activity assigned to this report. Suffice it to say, though, that cyber-activism has now become a parameter that one cannot avoid engaging with, to some extent, in any commentary on the character of current social contestation.

Although Greece lags behind its EU counterparts in terms of internet use by the general public, such use is undoubtedly on an unstoppable increase and in some notable instances has already demonstrated its capacity for disseminating information (protest issue, location, legal assistance, resources etc) which can support protest activity and campaigning. A notable role has been played by the Athenian section, $<$ Athens.Indymedia.org $>$, of the global IMC (Independent Media Centre), which was set up during the anti-globalization movement's landmark 1999 Seattle protests. This website has become a standard medium of alternative information which is extensively used by many social movement actors of radical left persuasion. It is closely monitored by the security services as well as by TV channels fishing for newsworthy events that have escaped their attention. Moreover, on the environmental front a number of citizen initiatives promoting the rights of cyclists and pedestrians ${ }^{3}$ have sprung up with an online presence and extensive use of email forums and lists as a coordinating mechanism. These have brought to Greece a new type of direct, peaceful, protest action. Examples include 'critical mass' ${ }^{4}$ and stickers aiming to shame the owners of vehicles parked on pavements or other sectors of the city dedicated to exclusive pedestrian use. ${ }^{5}$

While the webloggers community in Greece certainly has an older presence, it acquired a new visibility during 2007 thanks to the poignant postings made by a longterm health sufferer. In her personal weblog, ${ }^{6}$ Amalia Kalyvinou narrated the deteriorating progress of her devastating health condition with references to her adventures with an ailing health service marred by a Byzantine bureaucracy and unscrupulous consultants whose Hippocratic oath is conditioned by the value of the 'gift' given to them by the patient and his/her family. The blogger suffered a range of successive misdiagnoses and a series of consultants in public hospitals re-directing her to their private surgeries for a supposedly more detailed examination and a correspondingly generous fee. 


\section{J. Karamichas}

Any casual observer of Greek social reality is likely to have encountered similar stories which routinely enter everyday Greek conversation. However, these structural problems are accepted and ratified as normal by an individualistic attitude that prefers to sustain a negative situation by bypassing demands for improvements in the quality of the national health service for all, and investing instead in private health insurance with an immense financial impact on the family budget. ${ }^{7}$ The young patient's weblog would probably not have attracted the attention that it did if it had not been accessed by a journalist of a popular centre-left daily, Eleftherotypia, who subsequently interviewed her and brought her plight to general attention. Her untimely death, soon after the interview was published, was followed by a general expression of revulsion for this extremely negative state of affairs in health provision and to an online campaign, organized by the weblog community, with a commitment to keeping their fellow weblogger's story alive as a sober reminder to the general public.

However, the most important form of cyber-activism, in terms of acquiring the highest visibility, was the two protest events organized by the webloggers community ${ }^{8}$ in relation to the forest fires. The first call for a demonstration expressed public anger against what was seen as an ineffective and inefficient response by the state mechanism to the forest fire at the national nature reserve of Parnitha-which destroyed 10,500 acres of forest land-and demanded a guaranteed reinstatement of the lost area. The protest was initially called by a suggestion that appeared as a simple post on some weblogs and was quickly disseminated through text-messaging and emailing. Rather unexpectedly, a crowd variously estimated as ranging from 5,000 to 10,000 gathered outside the Greek parliament and the surrounding streets to participate in the protest event (8 July). This was a really impressive number for a protest event during the summer holiday season.

No one would have expected a similar event to take place in close chronological proximity. However, during August, Greece was hit by extensive forest fires, which engulfed almost the whole of southern Greece, with 170 different fronts raging simultaneously at one point. The state mechanism appeared naked in its capacity to deal with the fires and appealed for international help as it was confronted by a rising death toll. The fact the flames reached the world heritage site of Olympia substantially increased the international media coverage of this disaster. As a result, the weblog community called for another protest gathering in Athens on 29 August. This attracted twice the number of participants as the earlier event of 8 July and was mirrored by protests in other cities.

Going back to the position advocated by Sotiropoulos et al., the range of aid offered by ordinary Greeks and a variety of associations toward the communities that suffered from the fires, as well as the amazing courage exhibited by some locals in firefighting, can possibly be added to that spontaneous solidarity that Greeks seem to exhibit in times of unexpected disasters. This is missed by most dominant measurements of civil society strength, which mainly focus on quantifiable associational membership. Most importantly, the recent forest fires demonstrate the possible mainstreaming and diffusion of a new form of coordinating activism which is likely to move beyond the ad hoc character of environmental mobilizations in Greece. The following section provides 
a brief appraisal of the results of the latest Greek national elections, with an emphasis on the environmental problem and the electoral impact of the devastation caused by the forest fires.

\section{The Parliamentary Elections of 16 September 2007}

The national elections took place six months before the end of ND's four-year term in office. The call for early elections was orchestrated by the governing party as a way of reinforcing its position after a succession of serious economic scandals that had just started to reach the public domain. Meanwhile, a series of extremely encouraging electoral polls was still awarding ND the top position in voting preferences. The forest fires and the manifest inefficiency of the state mechanism in confronting them, undoubtedly caused a serious headache for the governing party, which made an unsuccessful attempt to postpone the elections, only to be confronted by a constitutional provision that permits such a development only in the case of a serious national threat, such as a declaration of war by a foreign power.

As the forest fires intensified, the government tried to initiate a defence strategy to minimize the negative impact of the devastation caused by the fires on its electoral performance, by promoting the discursive device of 'asymmetrical threat'. This was directly borrowed from the vocabulary used by the US government to justify any unpalatable action taken in relation to its 'war against terror'. The range of potential actors allegedly conspiring to destabilize the country through the forest fires was wideranging and the whole debate hit extremely high levels of ludicrousness, proper discussion of which would require a separate report.

The only excuse for the failure of the state mechanism successfully to combat the fires was the extreme climatic conditions that Greece experienced during the summer of 2007, with a combination of extremely high temperatures and strong gales. The latter made the work of both land and air firefighting services very difficult. Extreme climatic conditions, with high temperatures, can be blamed for the forest fires experienced this summer by a number of other South European states, such as Italy and Spain, and some neighbouring Balkan states, like Bulgaria. However, there is an undisputable correlation between climate change and 'natural' disasters, which is manifesting itself in different forms globally; for example increased temperatures in southern Europe and intense rainfall in the UK; the ascription of exclusive responsibility to climate change would amount to a complete disregard for an exploration of 'cause and effect'.

Climate change and its potential impact on Greece have been known for too long to justify the offguard situation in which the Greek state mechanism found itself. In addition, as already mentioned, forest fires have become an annual occurrence in Greece during the summer months. In fact, the EU had already assigned a budget of $€ 32$ million for forest protection, which the Greek state had failed to utilize. If one wishes to detect a conspiracy theory behind the forest fires, it would be much more productive to take into account the fact that Greece is the only EU country without 


\section{J. Karamichas}

detailed forest and housing/agricultural land logs and maps, and the fact that the ND government had planned to introduce changes to the constitutional Forest Protection Article (Article 24) which would have led to the de-classification of forest land and the opening of roads for various housing and development projects. So, with these widely known facts in mind, how did ND and the opposition parties fare in the recent national elections?

The 2007 election was contested under a new electoral system ratified in February 2004. Under this system, 260 out of the 300 seats in the Greek parliament are allocated through proportional representation, with the strongest party or party alliance receiving the remaining 40 seats. The three per cent threshold for parliamentary representation, introduced in the 1990s, is maintained. Contrary to the expectations of some sources, often drawing rather unqualified parallels with the impact of the Madrid terrorist bombings of 2004 on the electoral defeat of the Aznar government in Spain, ND again emerged victorious from the 2007 elections with 41.83 per cent of the vote. This amounts to a 3.73 per cent drop from its 2004 electoral support, which is, of course, an expected drop for a party elected for a second term in government. Nevertheless, in the context of the forest fires and the inefficiency shown by the state mechanism, one would have had expected a much higher decrease in ND's electoral leverage. Some commentators partly attribute the fact that this did not happen to a rapid distribution of funding to the electoral districts most affected by the forest fires immediately before the elections.

The leading opposition party, PASOK, also experienced a drop of 2.45 per cent of the total vote compared with the 2004 elections, with its vote falling to 38.10 per cent. So, PASOK not only failed to capitalize on the forest fires by increasing its vote but also achieved its lowest electoral score since the late 1970s. Leaving aside a range of other explanations for this poor electoral performance, it would be extremely optimistic to suggest that a PASOK government would have dealt more effectively with these forest fires. Furthermore, as has already been mentioned, the previous amendment of Article 24, with a similar purpose, took place under a PASOK government, was ratified in 2001 and coincided with the widespread and extremely costly forest fires of 2000 . These facts must have certainly dissuaded those voters who might have been influenced by recent events to channel their support to PASOK.

The electoral impact of the forest fires can only be detected in the substantial increase in the electoral percentages achieved by the parties of the left. The Greek Communist Party, KKE, achieved 8.15 per cent of the vote-a rise of 2.25 per cent in its share of the national vote since 2004-and 22 parliamentary seats, doubling its parliamentary representation.

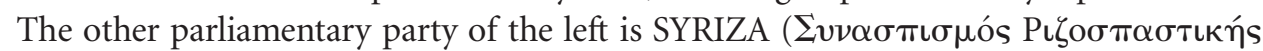

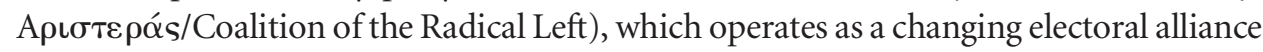

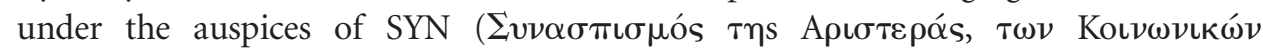

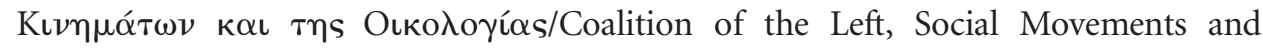
Ecology). SYN has a proven record of supporting the ecologization of Greek politics through both its parliamentary presence and its support for environmental initiatives. For example, it actively supported the seaside protests, which were visited several times by 
party leader Alecos Alavanos. SYRIZA gained 5.04 per cent of the vote-a jump of 1.78 per cent of the national vote compared with 2004-and 14 parliamentary seats, compared with six in the previous parliament. Also notable was the 1.05 per cent of the national vote

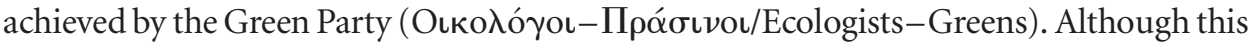
fell short of the three per cent threshold for parliamentary entry, it was striking that the Greens scored some of their highest electoral percentages in some of the electoral constituencies most devastated by the forest fires.

\section{Concluding Remarks}

Forest fires can cause devastating loss of both natural resources and human lives. In most cases, they can very easily be attributed to natural causes, albeit the duration and extent of damage caused are bound to be assessed in relation to the competence exhibited by the relevant authorities in combating them. One would also expect this to be the case for the action taken toward the recuperation of affected areas and the planning for combating similar incidents in the future. The extent of the devastating forest fires in Greece during the summer of 2007 has prohibited any ascription of blame to natural causes. In any case, the latter were known about early enough to allow for their factoring into any forest protection planning, whilst the response of the state mechanism was offguard and spasmodic, giving insufficient effort to adequately tackling the event in its infancy. In addition, by placing the 2007 forest fires in the context of attempts to revise constitutional Article 24 in conjunction with the absence of a partially completed land and forest register, a much more inclusive exploration of 'cause and effect' was offered.

When it comes to broadly defined environmental issues, similarly suspicious concurrences have been identified whereby-irrespective of the fact that in certain cases the environmental concern of the locals coincided with other covert intereststhe administration has approved environmentally damaging activities as part of its own projects, in flagrant violation of existing legal frameworks, or has failed to monitor and police effectively the expansion of private business interests. These often result in confrontation between the state and the locals. The mobilizations related to the 2007 forest fires seem to signify the opening of a new chapter in the informality and spontaneity that seem to characterize Greek civil society. The latter appears to be moving beyond the ad hoc (i.e. spontaneous, temporal and for a specific purpose) expression of a mobilizing dynamic to the more permanent locations that can be afforded by cyberspace.

The protest vote mentality that certainly penetrated the 2007 national elections can to a great extent be held responsible for the substantial increase in the votes of the leftwing parties, one of which, SYN, has an explicit commitment to a political ecology outlook. The extent to which this substantial change in the parliamentary presence of these parties will become a permanent feature of Greek parliamentary politics will be determined by the exigencies of the next electoral round. What is certain is that the vigilance required at the grassroots level in order to protect what is left of the Greek 


\section{J. Karamichas}

forests has much stronger actors occupying parliamentary seats with whom civil society can ally.

\section{Notes}

[1] Data from EFFIS (European Forest Fires Information System) of IES, < http://effis.jrc.it/ Home/>.

[2] In particular, the Greek Church, one of the country's largest landowners, enjoys the privilege of its

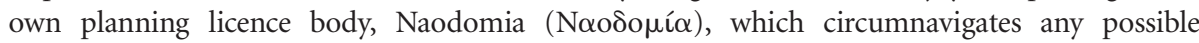
objections to its building operations that it could have encountered from the town-planning department.

[3] The cyclist groups disseminate their activities through the newsgroup <Email: podilato@ yahoogroups.com $>$ and the webpages $<$ www.podilates.gr $>>$ and $<$ http://www.podilatreis.gr $>$, and the pedestrian group uses the webpage $<$ www.pezh.gr $>$.

[4] This is a protest activity taking place regularly in many cities around the world with the aim of reclaiming the streets from cars. It brings together mainly cyclists but also other self-propelled commuters (pedestrians, skateboarders, rollerskaters, etc.).

[5] This type of guerrilla stickering has been promoted by the weblog $<$ http://streetpanthers. blogspot.com/ $>$.

[6] Amalia's weblog, < http://fakellaki.blogspot.com/ $>$, was named after a term used in everyday parlance to suggest bribing: fakellaki, literally meaning 'small envelope'.

[7] A similar attitude is also evident in the educational sector, where Greek families spend a substantial percentage of their budget on private tuition to increase their offspring's chances of entry to higher education or improve their employment prospects.

[8] 'Blogs' are frequently updated webpages on which authors post their comments on current events and their personal thoughts and interests.

\section{References}

Close, D. (1998) 'Environmental NGOs in Greece: the Achelöos campaign as a case study of their influence', Environmental Politics, vol. 7, no. 2, pp. 55-77.

Close, D. (1999) 'Environmental crisis in Greece and recent challenges to centralized state authority', Journal of Modern Greek Studies, vol. 17, pp. 325-352.

European Commission (1999) Eurobarometer, no. 51, European Commission, Brussels.

Friedman, T. L. (2006) The World Is Flat. The Globalized World in the Twenty-First Century, Penguin, London.

Hofrichter, J. \& Reif, K. (1990) 'Evolution of environmental attitudes in the European Community', Scandinavian Political Studies, vol. 13, no. 2, pp. 119-146.

IES (2005) Forest Fires in Europe 2004, Directorate General, Joint Research Centre, Brussels.

Karamichas, J. (2005) 'Risk versus national pride. Conflicting discourses over the construction of a high voltage power station in the Athens metropolitan area for demands of the 2004 Olympics', Human Ecology Review, vol. 12, no. 2, pp. 133-142.

Karamichas, J. \& Botetzagias, I. (2003) 'Green party factionalism. The case of the Federation of Ecologists Alternatives (FEA) of Greece', South European Society \& Politics, vol. 8, no. 3, pp. $64-92$.

Kousis, M. (1994) 'Environment and the state in the EU periphery: the case of Greece', in The Politics of Sustainable Development, eds. S. Baker, M. Kousis, D. Richardson \& S. Young, Routledge, London, pp. 118-135. 
Kousis, M. (1994) 'Environment and the State in the EU periphery: the case of Greece', in Protecting the periphery, environmental policy in peripheral regions of the European Union, eds. S. Baker, K. Milton \& S. T. Yearly, Frank Cass, London, pp. 118-135.

La Spina, A. \& Sciortino, G. (1993) 'Common agenda, southern rules: European integration and environmental change in the Mediterranean states', in European Integration \& Environmental Policy, eds J. D. Liefferink, P. D. Lowe \& P. J. Mol, Belhaven Press, London/New York, pp. 99-113.

Mota, F. (1999) 'La Realidad Asociativa en España', in ¿Existe sociedad civil en España?, ed. J. Subirats, Fundación Encuentro, Madrid, pp. 37-64.

Pridham, G. \& Cini, M. (1994) 'Environmental standards in the European Union: is there a southern problem?', in Environmental Standards in the EU in an Interdisciplinary Framework, eds M. Faure, J. Vervaele \& A. Weale, Maklu, Antwerp, pp. 251-277.

Rohrschneider, R. (1988) 'Citizen's attitudes toward environmental issues. Selfish or selfless?', Comparative Political Studies, vol. 21, no. 3, pp. 347-367.

Rüdig, W. (1995) 'Public opinion and global warming', Strathclyde Papers on Government and Politics, no. 101, pp. 1-39.

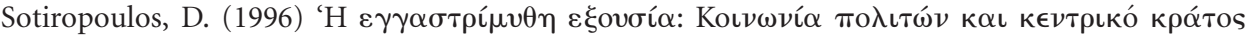

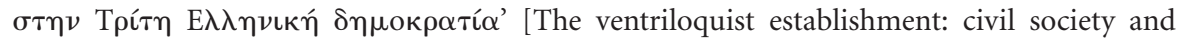

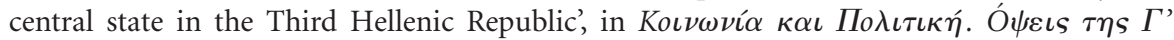

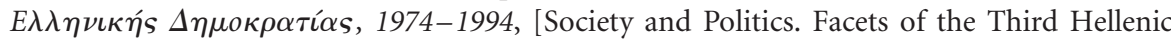
Republic, 1974-1994] eds Ch. Lyrintzis, E. Nikolakopoulos \& D. Sotiropoulos, Themelio, Athens, pp. 119-138.

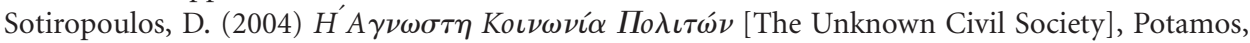
Athens. 